\title{
To be connected: Supporting self-regulated learning in higher music education before and during the pandemic
}

\section{Dejana Mutavdžin ${ }^{1}$}

Faculty of Music, University of Arts in Belgrade

\section{Milan Stančić}

Faculty of Philosophy, University of Belgrade

\section{Blanka Bogunović}

Faculty of Music, University of Arts in Belgrade

\begin{abstract}
In online learning, students are expected to take on more responsibility for their education, while teachers are expected to support students' self-regulated learning (SRL) skills. In this research, we explore whether young musicians perceive a difference in the actions that their major music teacher (MMT) took to support their SRL skills before and during the pandemic, and investigate their view on how the MMT could further support their learning. The sample included 144 students of the Faculty of Music in Belgrade, who filled in the online inventory comprised of 24 questions - 17 parallel Likert-type items (referring to the MMT's actions supporting SRL skills, before and during the pandemic), and one question was a short letter to the MMT. Data were analysed using dependent $t$-test, ANOVA and reflexive thematic analysis. Students perceived that SRL skills were more encouraged before than during the pandemic. Additionally, our findings show that music students who did not have in-person and online communication, separately, with their MMTs perceived they had lower support to self-regulate their learning. The findings from qualitative analysis inform educational practice by pointing to specific teacher's actions that students perceive as important for their further development.
\end{abstract}

Keywords: self-regulated learning, COVID-19, teachers' support, music teacher, higher music education.

In a quest to improve the quality of education, self-regulated learning (SRL) is often perceived as a Holy Grail. SRL has become one of the main concepts in educational sciences as it is recognized as the core competence

1 dejana.mutavdzin@outlook.com 
required for learning to learn, i.e. for becoming a lifelong learner. Even though there are many SRL models, they highlight similar characteristics of the SRL process - it is a cyclical process that includes cognition, metacognition, motivation, behaviour, and emotions, and it is comprised of a set of skills that can be developed (Panadero, 2017; Panadero \& Alonso-Tapia, 2014). In essence, self-regulated learning occurs when a student has systematic control of motivation, thought, and behaviour in pursuit of learning goals (Zimmerman \& Moylan, 2009). In this study, we rely on Zimmerman's cyclical model of SRL (Zimmerman \& Campillo, 2003). This model consists of three cyclical phases: (a) the Forethought phase, when students analyse the task, set goals and plan how to reach them, and activate motivational beliefs and learning strategies; (b) the Performance phase, when students execute the plan, which includes the use of self-control and self-observation strategies to monitor the progress and maintain motivation; and (c) the Self-reflection phase, when students assess how well they have performed the task and make attributions about their success or failure which can, in turn, positively or negatively influence how students approach tasks in the future (Panadero, 2017; Panadero \& Alonso-Tapia, 2014; Zimmerman \& Moylan, 2009).

In this paper, we deal with teachers' support to SRL in higher music education (HME) before and during the COVID-19 pandemic in Serbia. As SRL is often considered crucial for high instrumental and interpretative performance skills, and online education in the time of the pandemic demands and favours students who are good in self-regulation, the specific context in which we examine SRL in this study could be considered especially intriguing, so as to say - double trouble.

\section{Online higher education in the time of the pandemic: Why SRL matters?}

The COVID-19 pandemic is nowadays commonly referred to as one of the greatest disrupts in education in recent history. In most parts of the world, schools and universities were closed in the early spring of 2020, and many still operate, totally or partially, in an online teaching/learning mode. According to some analyses, responses by higher education providers were diverse from having no response, through meeting basic government requirements for social distancing on campus, to emergency curriculum redevelopment to provide fully online education to students (Crawford et al., 2020).

Even though online learning can include synchronous communication with the teacher and peers, many online courses at universities today are organized in the form of asynchronous and self-paced learning. However, such a manner of work may result in reduced opportunities for interaction with the teacher and peers (Wang et al., 2013). Moreover, online learners are often expected to structure their learning, determine when and how to engage with course content and tasks, manage their time efficiently, etc. 
(Broadbent, 2017; Moore \& Kearsley, 2005). Therefore, to learn effectively in an online environment, students are expected to be self-regulated, i.e. to be autonomous in planning and monitoring of own learning (Broadbent, 2017; Broadbent \& Poon, 2015; Dabbagh \& Kitsantas, 2004; Serdyukov \& Hill, 2013; Wang et al., 2013). As studies suggest, students who had had prior experience with online learning also had more effective learning strategies than those who did not have such experience (King et al., 2000; Wang et al., 2013). Therefore, support to students' capacities for SRL could be considered a matter of priority in the pandemic, given that it was the first encounter with online learning for many students.

Previous research has shown that students performed better in online learning using SRL strategies, than when they did not use them (Anthonysamy et al., 2020; Barnard-Brak et al., 2010; Broadbent \& Poon, 2015; Broadbent \& Fuller-Tyszkiewicz, 2018; Puzziferro, 2008; Wang et al., 2013). There are only a few studies on SRL in higher education during the time of the pandemic. Studies show that students with self-efficacy in self-regulation reported lower study related stress during the pandemic (Keyserlingk et al., 2021), while self-organization skills were found to be positively correlated with learning achievement (Klein et al., 2021).

\section{Higher music education and SRL}

It is argued in the literature that SRL is inherent to music education, as "understanding how musicians reach the highest levels of musical achievement involves understanding how they think about the task, themselves, and their performance, as well as the amount of time they spend practicing" (McPherson et al., 2017, p. 19). Empirical studies with advanced musicians indeed show that they rely greatly on self-regulation in their practice (Araújo, 2015). Therefore, future musicians need to learn how to integrate efforts they put into practicing, which by itself is not sufficient for becoming an expert musician, with SRL skills that should help them to systematically monitor their thoughts, feelings, and actions as they strive to reach their learning goals (McPherson et al., 2017; Miksza, 2015; Miksza et al., 2018; Nielsen, 2015). Looking at a wider scale, it is quite likely that most of the musicians have never received proper instruction on how to use SRL (Hatfield et al., 2016; Miksza et al., 2018). However, studies show that complementing traditional practicing activities (such as slowing and repetition) with support for SRL (instructing students on goal setting, planning of learning, self-evaluation, reflection etc.) significantly improves the performance of tertiary music students (McPherson et al., 2017; Miksza, 2015). Several research studies have found that more selfregulated music students tend to report being more self-efficacious, display greater determination towards goals, spend more time practicing, demonstrate metacognition and self-awareness while practicing, are more proactive, and 
tend to employ a variety of practice strategies (Boon, 2020; Hatfield et al., 2016; Miksza, 2011; Miksza \& Tan, 2015; Miksza et al., 2018).

Several research studies on HME were conducted in Serbia using the SRL theory as a background. The SRL model, developed by Zimmerman and Campillo (2003), was used and adapted for the research of sight-reading music while playing or singing as self-regulated performance (Bogunović et al., 2020; Bogunović \& Vujović, 2012). It was confirmed that co-cognitive factors, i.e. the particular pattern of personality and motivational attributes, measured by the NEO-P-R, had a certain role in efficient self-regulated performance, especially in the Preparation and Performance phases, such as Emotional stability, Competence, Dutifulness, Achievement striving, Discipline, and Deliberate thinking (Bogunović, 2018).

The SRL studies that were specifically related to HME in the online context are not common. One recent study on SRL in blended learning within music education showed that SRL behaviours correlated with academic achievement, whereby regularity of student's access to the learning platform was the strongest predictor of student success (Montgomery et al., 2019). Another study, although not focused specifically on SRL, provided valuable insights on certain aspects of SRL (goal-setting, task analysis, intrinsic motivation, self-control) that are important for learning online in the time of pandemic. Namely, it was found that the impact of COVID-19 reflected negatively on music students who expressed a need for clear goals and total concentration, while students who felt that their skills matched the challenges of a situation and frequently had autotelic experiences, were able to use the impact of COVID-19 to their advantage (Habe et al., 2021).

\section{(Music) teacher support to SRL in higher education}

Despite widespread agreement on the importance of SRL, not all university teachers embed support for SRL into their teaching (Russell et al., 2020). Moreover, it is often assumed that students are already proficient in SRL (Bjork et al., 2013; Russell et al., 2020), whereas studies show that they are usually not adequately prepared for the expectations related to learning that await them at the university (Christie et al., 2013; Heikkilä et al., 2012) and do not use digital technologies to regulate their learning (Yot-Domínguez \& Marcelo, 2017). Therefore, much emphasis needs to be placed on enhancing students' SRL skills through the careful design of learning and assessment activities. In general, teachers should provide both direct instruction and opportunities for students to practice SRL. We wonder to what extent university teachers support SRL development or whether take it for granted, especially in the HME, where the role of the major music teacher (MMT) is fairly prominent. 
One previous study has found that teacher's engagement in self-regulation, especially when it is made visible to students, plays a key role in promoting SRL among students (Russell et al., 2020). Guided and independent practicing is another way to help improve students' SRL, which implies that students are given opportunities to practice different learning strategies, while the teacher observes and offers help if it is needed, intending to strengthen students' independent use of strategies (Lee et al., 2010; Schunk \& Zimmerman, 2007). Studies show that teachers who are more motivated to design their teaching to foster SRL had the following characteristics: their pedagogical beliefs were aligned with SRL theory; they tended to self-regulate their work and learning; they had a sense of agency (believed that they could adapt the curriculum to achieve their teaching goals); they were eager to experiment and reflective; and they valued lifelong learning, student's participation, listening and understanding students (Moos \& Ringdal, 2012; Russell et al., 2020).

As for HME, direct instruction, e.g. video instruction on the principles of SRL and practice behaviours, seems to be effective in terms of improving music students' performance and self-efficacy (Miksza, 2015). Special training programmes for music students aimed to support their SRL skills were also shown to help enhance students' concentration, self-efficacy, selfreflection, coping skills, and reduce their performance anxiety (Hatfield, 2016). Microanalysis, as a structured interview involving context-specific questions while the respondent is engaged in an authentic activity, is recognized as an effective tool to investigate SRL but also to support it in music students' practice, i.e. to cue students to think about what they are doing and reflect critically on the strategies they can use to improve their performance (McPherson et al., 2017; Miksza et al., 2018). Studies show that it is a useful aid for reflection on students' specific self-regulatory deficiencies and for addressing them in a manner respective to their needs (McPherson et al., 2017; Miksza et al., 2018).

In HME, the MMT's position and role are more specific, especially in the time of the pandemic, because teaching takes place in a one-to-one setting or small groups. Therefore, teacher's role and responsibility are essential for SRL, as well as for the outcomes of tuition and further professional career. Usually, the master-apprentice type of relationship is present, as opposed to the mentor-friend (Reid, 1997). This type of relationship is often characterized by tension between teachers' aspirations to facilitate student autonomy in learning and the transmission-oriented teaching process. Namely, studies show that teaching technical and musical skills primarily through teacherled reflection-in-action could inhibit the development of students' selfresponsibility and an individual artistic voice (Gaunt, 2007). From the students' perspective, tension emerges between trust in a single teacher and the way in which teachers encourage students to become more responsible for their learning. Namely, the development of planning and reflective 
strategies, related to either learning processes or professional performing career development, were rarely prioritized (Gaunt, 2010). Similar results were gained in HME in Serbia - even though the indisputable value of individual vocal/instrumental tuition has been confirmed, findings point to the existence of a traditional pattern in the 'desired' teacher's attributes, i.e. the teacher/master-apprentice relationship model, with the prevailing oneway communication (Bogunović \& Mirović, 2014).

Taking into account the importance of SRL in HME and a lack of research on whether and how it could be supported in an online teaching/ learning context, our research aims to investigate to what extent and how SRL is fostered by the MMT, perceived by students, before and during the COVID-19 pandemic in Serbia. In addition, we wanted to explore students' opinions on the ways in which the MMT can further support the acquisition of SRL skills and musical development in the online setting.

\section{Method}

\section{Sample}

The convenience sample $(N=144)$ consisted of 88 undergraduate and 56 graduate students from the Faculty of Music (FoM) in Belgrade, aged 18 to $45(M=23.10, S D=3.98), 53$ males and 91 females. The sample included students from music performing (82) and theoretical (62) departments, and represents approximately $19 \%$ of the students who attended the FoM during that school year.

Students completed the survey during regular classes of psychology courses at the end of the winter semester 2021 (this was the second semester during which some of the classes were not held in person, and the semester during which a relatively coherent solution for teaching was found at the FoM). They were informed about the purpose of the study, confidentiality was guaranteed and students had the opportunity to refuse to participate in the research, as well as to withdraw from the research at any time.

\section{Instrument}

The questionnaire was designed for the purposes of the study. It contained 32 questions distributed in three parts, but for the purpose of this paper, the answers collected on 24 questions are analysed. The first part of the instrument had 6 questions concerning: general data (age, gender, study level, department, and the major subject average grade) and the average number of in-person and the average number of online student-teacher per week contacts during the pandemic ( 2 items; 0-10 scale, assuming it was unlikely 
that there could have been more than 10 in-person and 10 online per-week contacts, separately).

The second part of the questionnaire (SRL scale) comprised 17 parallel Likert-type (1-7 scale) items, referring to the period before and during the pandemic (from October 2020 until the moment the data were collected). Each item stated the specific teachers' actions that could foster students' SRL skills concerning vocal-instrumental practicing/composing music/learning materials since these are the activities typical for the students of different departments. Participants were asked to assess the degree to which their MMT was supporting their SRL behaviour. Items were organized into 3 subscales, in line with the cyclical SRL model (Zimmerman \& Campillo, 2003), representing the Forethought phase (6 items - the MMT suggests making the work/timeline plan based on task analysis, setting long-term, specific and realistic goals, assessing the success probability, building up awareness of the task importance for the student development), the Performance phase (6 items - the MMT encourages a student to monitor own progress, to seek for assistance when needed, to pay attention to difficult parts, to use mental rehearsing strategies, to challenge oneself) and the Self-reflection phase (5 items - the MMT encourages a student to summarize what has been achieved after each learning session, to think about the possible causes of the mistakes that occurred and make a plan for overcoming them, to take time to think about how satisfied he/she is with the achievement, and to assess how close he/she is to achieving the goal). Initially, 34 parallel items were derived from Zimmerman and Campillo's model (2003), and Peter Miksza's work (2011, 2015; Miksza et al., 2018), and subsequently adapted to the specificities of the FoM's curriculum. In order to make the questionnaire time efficient and constructed of the same length subscales, through logical analysis, 17 parallel items that best corresponded to the research aim were selected. Two principal component analyses confirmed a 3-component solution; the SRL subscales had adequate internal consistencies (the value of Cronbach's alpha ranging from .75 to .90; see Appendix A).

The third part of the instrument contained a request for participants to write a short message/letter to their MMT with the suggestions on how to support him/her in further performing/composing/learning process, based on the collaboration experience with the MMT during the pandemic.

\section{Procedure}

Data collection was performed in January 2021. The questionnaire was administered in an online form (Qualtrics XM), and took 30 to 60 minutes to be filled in.

The approval of the FoM's Ethics commission was obtained (No. 1559/20). 


\section{Data analysis}

Data were analysed using both quantitative and qualitative methods. For quantitative analysis, IBM SPSS Statistics 21.0 software for Windows was used ( $t$-test and ANOVA), and MAXQDA 2018 was used to support the qualitative analysis. Since we strived to capture both the semantic and latent meanings (Braun \& Clarke, 2020a; 2020b) of the obtained data, reflexive thematic analysis was applied for the analysis of students' letters/messages to the MMT, following the steps provided by Braun and Clarke (2006). After familiarizing with the data and creating initial notes, we performed a systematic inductive coding of the data. Initial first-level codes that were similar in their content were later on grouped under the second-level codes. In the further course of the analysis, two key themes were generated and their belonging codes were specified (see Table 5).

\section{Results}

Differences in students' perceptions of the MMT's support in fostering the SRL skills before and during the pandemic

Descriptive statistics for the SRL scale and its subscales referring to the period before and period during the pandemic, separately, are presented in Table 1.

Table 1

Means and standard deviations of scores on the SRL scale and its subscales for the periods before and during the pandemic

\begin{tabular}{llcccc}
\hline \multirow{2}{*}{ Score } & & \multicolumn{2}{c}{ Before } & \multicolumn{2}{c}{ During } \\
\cline { 3 - 6 } & & $M$ & $S D$ & $M$ & $S D$ \\
\hline SRL scale & & 85.77 & 20.13 & 83.51 & 23.11 \\
& Forethought subscale & 30.34 & 8.37 & 29.85 & 9.04 \\
& Performance subscale & 32.09 & 6.84 & 30.77 & 8.33 \\
& Self-reflection subscale & 23.15 & 7.20 & 22.56 & 7.88 \\
\hline
\end{tabular}

When comparing the arithmetic means of the parallel SRL scale scores, it was found that students perceived that the MMT had supported them to foster SRL skills to a greater extent before than during the pandemic, $t(135)$ $=2.29, p<.05, r_{p b}=.19$. By comparing the means of parallel subscales, it was found that students assessed that their MMT had supported them in the Performance phase to a greater extent before than during the pandemic, $t(140)=3.10, p<.01, r_{p b}=.25$.

Since we wanted to examine whether students' contact frequency with the MMT per week had a role in the perceived difference in the SRL support, 
some data transformation had to be made. The average number of in-person and the average number of online student-teacher contacts per week during the pandemic were among the control variables in this research (range 0-10, each). Based on the distribution of responses, these two variables, separately, were transformed into two categorical ones. In order to make relatively balanced groups on both variables, responses were divided into three groups presented in Table 2.

Table 2

Number of in-person and online student-teacher per week contacts during the pandemic: Means, standard deviations, and distribution of respondents into groups

\begin{tabular}{lccccc}
\hline Modalities & $M$ & $S D$ & $\begin{array}{c}n \text { Group } 1 \\
(0 \text { contacts })\end{array}$ & $\begin{array}{c}n \text { Group 2 } \\
(1 \text { to } 2 \text { contacts })\end{array}$ & $\begin{array}{c}n \text { Group 3 } \\
(\geq 3 \text { contacts })\end{array}$ \\
\hline In-person & 1.83 & 1.98 & 33 & 64 & 29 \\
Online & 2.35 & 2.49 & 19 & 72 & 35 \\
\hline
\end{tabular}

In order to explore whether our respondents perceived a difference in the actions that their MMTs had taken before and during the pandemic to support their SRL skills, we created four composite variables. Scores obtained on the SRL scale and its subscales, separately, referring to the period during the pandemic, were subtracted from parallel scores on the scale and three subscales referring to the period before the pandemic. These new variables present the perceived differences in the MMT's support to SRL skills received before and during the pandemic, for the whole SRL scale and for the Forethought, Performance, and Self-reflection subscale, separately.

Groups based on the frequency of in-person contacts. As can be seen in Table 3, ANOVA showed a significant effect of an average number of in-person student-teacher per week contacts in each of the three groups concerning the difference in the SRL support received before and during the pandemic. A significant effect of the average number of student-teacher in-person per week contacts on the levels of the perceived difference in support before and during the pandemic was found in each of the three phases. The results of Hochberg's post hoc test suggest that all of the observed differences were due to students who had no in-person contact with their MMT during the pandemic. These students perceived a greater difference both in total SRL support and in the support in each of the SRL phases compared to the students who had one or more such contacts with the MMT per week. 
Table 3

Means, standard deviations and two-way ANOVA statistics for the perceived differences in the MMT's support to the SRL skills before and during the pandemic, for the SRL scale and its subscales, for in-person student-teacher contacts

\begin{tabular}{|c|c|c|c|c|c|c|c|c|c|c|c|c|}
\hline \multirow{2}{*}{$\begin{array}{l}\text { Difference in } \\
\text { parallel scores }\end{array}$} & \multicolumn{2}{|c|}{ G1 } & \multicolumn{2}{|c|}{ G2 } & \multicolumn{2}{|c|}{ G3 } & & \multirow{2}{*}{$d f$} & & \multicolumn{3}{|c|}{ Hochberg's post hoc test ${ }^{\mathrm{a}}$} \\
\hline & $M$ & $S D$ & $M$ & $S D$ & $M$ & $S D$ & & & & $\overline{\mathrm{G} 1-\mathrm{G} 2}$ & G1-G3 & G2-G3 \\
\hline SRL scale & 8.31 & 20.23 & 0.63 & 6.70 & -0.04 & 4.22 & $5.94^{\star \star}$ & 2,129 & .26 & $\mathrm{Y}$ & $\mathrm{Y}$ & $\mathrm{N}$ \\
\hline $\begin{array}{l}\text { Forethought } \\
\text { subscale }\end{array}$ & 2.36 & 6.02 & -0.03 & 2.85 & -0.18 & 2.26 & $5.19^{* *}$ & 2,133 & .24 & $\mathrm{Y}$ & $\mathrm{Y}$ & $\mathrm{N}$ \\
\hline $\begin{array}{l}\text { Performance } \\
\text { subscale }\end{array}$ & 3.79 & 8.51 & 0.71 & 3.48 & 0.28 & 1.77 & $5.29^{* *}$ & 2,134 & .24 & $\mathrm{Y}$ & $\mathrm{Y}$ & $\mathrm{N}$ \\
\hline $\begin{array}{l}\text { Self-reflection } \\
\text { subscale }\end{array}$ & 2.44 & 6.67 & 0.15 & 2.06 & -0.21 & 1.17 & $5.38^{* *}$ & 2,131 & .25 & $\mathrm{Y}$ & $\mathrm{Y}$ & $\mathrm{N}$ \\
\hline
\end{tabular}

Note. G1 = Group 1, G2 = Group 2, G3 = Group 3

${ }^{a}$ Statistically significant difference between two groups, $\mathrm{Y}=$ found, $\mathrm{N}=$ was not found ${ }^{* *} p<.01$

Groups based on the frequency of online contacts. There was a significant effect of the average number of online student-teacher per week contacts on the levels of the perceived difference in the SRL support received before and during the pandemic, as can be seen in Table 4. The results of Hochberg's post hoc test suggest that students who had no online contact with the MMT during the pandemic perceived greater difference in the SRL support than the students who had one or two per week contact with the MMT. The effect of the average number of student-teacher online per week contacts on the levels of the perceived difference in the support that students had received before and during the pandemic in fostering skills referring to the Performance phase was also found.

Table 4

Means, standard deviations and two-way ANOVA statistics for the perceived differences in MMT's support to SRL skills before and during the pandemic, for the SRL scale and its subscales, for online student-teacher contacts

\begin{tabular}{|c|c|c|c|c|c|c|c|c|c|c|c|c|}
\hline \multirow{2}{*}{$\begin{array}{l}\text { Difference in } \\
\text { parallel scores }\end{array}$} & \multicolumn{2}{|c|}{ G1 } & \multicolumn{2}{|c|}{$\mathrm{G} 2$} & \multicolumn{2}{|c|}{ G3 } & \multirow{2}{*}{$F$} & \multirow{2}{*}{$d f$} & \multirow{2}{*}{$\omega$} & \multicolumn{3}{|c|}{ Hochberg's post hoc test } \\
\hline & $M$ & $S D$ & $M$ & $S D$ & $M$ & $S D$ & & & & G1-G2 & G1-G3 & G2-G3 \\
\hline SRL scale & 9.44 & 23.67 & 1.16 & 9.46 & 1.72 & 4.72 & $3.66^{*}$ & 2,120 & .20 & $\mathrm{Y}$ & $\mathrm{N}$ & $\mathrm{N}$ \\
\hline $\begin{array}{l}\text { Forethought } \\
\text { subscale }\end{array}$ & 2.61 & 7.29 & 0.08 & 3.08 & 0.61 & 3.20 & 2.96 & 2,123 & & & & \\
\hline $\begin{array}{l}\text { Performance } \\
\text { subscale }\end{array}$ & 4.28 & 9.22 & 1.08 & 4.76 & 0.76 & 2.42 & $3.19^{*}$ & 2,125 & .18 & $\mathrm{~N}$ & $\mathrm{~N}$ & $\mathrm{~N}$ \\
\hline $\begin{array}{l}\text { Self-reflection } \\
\text { subscale }\end{array}$ & 2.56 & 7.48 & 0.26 & 3.17 & 0.50 & 1.72 & 2.64 & 2,121 & & & & \\
\hline
\end{tabular}


There was no statistically significant effect of the respondent's age, sex, the average grade in the major subject, the department in which the student is enrolled or the cycle of studies on the level of the perceived difference in fostering the SRL skills before and during the pandemic.

\section{Students' perspective on the support they need}

When it comes to writing a short letter/message to the MMT, eight of the 144 respondents chose not to write it. After the initial reading, 20 letters were excluded from the analysis because they did not contain specific suggestions to the MMT on how to further support students' learning, but mainly expressed students' gratitude and content with the MMT's approach, and stated that they had nothing to suggest or add (e.g. "I would not add or change anything, and I completely agree with my major teacher's work so far."). Data analysis was conducted on the content of 116 letters. Some letters, or their parts, conveyed the message that there was no improvement needed, while in others, space for improvement was perceived. Table 5 presents the two key themes that were generated through the analysis, as well as their belonging codes.

Table 5

Key themes and corresponding codes generated in the letter analysis

\begin{tabular}{lll}
\hline Key theme & First- and second-level codes (number of coded segments) \\
\hline $\begin{array}{l}\text { Teacher } \\
\text { needs to } \\
\text { (do)... }\end{array}$ & give instructions & $\begin{array}{l}\text { containing additional information (17) } \\
\text { through feedback (11) } \\
\text { that are individualized (5) } \\
\text { that challenge students' abilities (5) } \\
\text { that encourage students' independence (3) } \\
\end{array}$ \\
& $\begin{array}{l}\text { organize } \\
\text { continuous/frequent classes and consultations (22) } \\
\text { different teaching modalities (17) }\end{array}$ \\
& provide & $\begin{array}{l}\text { access to information source (7) } \\
\text { opportunities to perform in front of an audience (6) }\end{array}$ \\
& motivate (13) & \\
& put an effort (10) & \\
\hline $\begin{array}{l}\text { Teacher } \\
\text { needs to be... }\end{array}$ & supportive (37) & \\
& devoted to teaching and students (25) \\
& close(r) (10) & \\
& open-minded (4) & \\
& less demanding (3)
\end{tabular}

Codes and 119 coded segments within Theme 1 describe the practices of a supportive MMT - what students expect the MMT to do and what the MMT is already doing to support their learning. When it comes to giving 
instructions, students often mentioned providing additional instructions, explanations, examples, information (e.g. "A couple of professors just lecture, some don't even do that, but just send the lesson, and they don't ask us at all if any part isn't clear to us and if we would like him/her to explain it again, I think they should work on that.") and, also, feedback. Some participants expressed the opinion that the MMT who supported musical development tailored his/her approach to the particular student, encouraged students' independence (e.g. "[...] and then to let me play my music, and to correct only stylistic mistakes that happen. This way I just copy his way of playing, which is a waste of time for me.") and challenged their abilities with the big amount of tasks and task requirements. Additionally, respondents pointed out to the importance of frequently held classes and consultations, not losing continuity, the importance of face-to-face encounters, as well as to the need for synchronous online communication; a part of the coded segments within this code indicated some asynchronous online communication's advantages (e.g. "Sending recordings is a great thing, it trains absolute accuracy, so it is possible to do it even when the teaching is face-to-face."). Segments in the third code within this theme indicated that the MMT is expected to provide access to information sources needed for learning/practicing and assignments, as well as to provide opportunities for students to perform, regardless of the performance's modality (online or in-person) and the persons in the audience (class colleagues or concert audience). The motivational potential of some of the MMT's activities was also pointed out (e.g. "It doesn't matter that we are at the faculty and that no one should force us to practice because it is our responsibility, it would still help a lot if the professors would check the students from-time-to-time, to motivate them and try to help them regain motivation."). Finally, students noticed when the MMT made an effort and, in most of these coded segments, they expressed gratitude because of it.

Seventy-nine coded segments made up the codes within Theme 2 . They describe the qualities the MMT has or should have and what the MMT should be like in order for the musically gifted students to perceive and feel he/she helps them to learn and progress. Students felt that the MMT was supportive when he/she was 'there' for students, showed interest in their wellbeing and understanding when it comes to mistakes they made (e.g. "[...] to show concern why I didn't send the recording for three weeks or asked for advice or something like that."). Students felt supported when the MMT was available for providing them help or advice, when he/she maintained contact (online or offline) and spent time with them (e.g. "[...] distance learning truly distanced me from the professor whose help I needed many times over."). The MMT encourages students' musical development by being devoted to teaching and students, which is expressed through responsibility, interest, desire, enthusiasm, and initiative when teaching, by transferring responsible work attitude to students, by being student-centred, and even by showing patience 
while teaching. According to our respondents, the MMT who helps students' progress is open to new information and students' perspective and, finally, adapts his/her approach to current circumstances by being less demanding when it comes to the amount of material and shows flexibility with deadlines.

\section{Discussion}

If we start from the 'double trouble' issue at the beginning of this paper, what do our data tell us? How well were music students supported by their MMTs to self-regulate their learning before and during the pandemic, how responsive were they to the performing/composing/learning and psychological needs of their students?

Examining the differences between students' perceptions of the MMT's support to their SRL skills before and during the pandemic, we have found that students' perception was that MMTs supported them to a greater extent before the pandemic than during the pandemic, especially in the Performance phase of the SRL process. Namely, students perceived that before the pandemic, the MMT had encouraged them more to build up awareness of the task importance, challenge themselves, engage in mental practicing, apply problem-solving strategies when facing difficulties, and summarize what had been achieved after each session (see Appendix B). The Performance phase is undoubtedly essential for music skills development (technical and interpretative), whereas the MMT's ongoing evaluation and feedback, which 'mirrors' skills execution and enhancing, is vital for student's advancement (McPherson \& Zimmerman, 2011).

Our findings show that music students who did not have in-person communication with their MMTs had less support to self-regulate their learning. Students who had at least one in-person contact per week gained beneficial cognitive (to make a plan, to engage in solving problems, to pay attention to difficulties) and motivational (to make a long-term plan, to challenge oneself) interventions and reflexive suggestions (to do a periodic assessment, to make a plan to overcome mistakes, to evaluate task success; see Appendix C). When it comes to online communication, students who did not have online contact with their MMT were deprived of some suggestions (how to make specific goals, seek help, how to do mental rehearsing; see Appendix D). From these data, we have learned that in-person interaction, at least once a week, brings more fruit as the MMT's interventions per contact, aimed to support SRL, are more numerous, instructive, and stimulative. Our findings also indicate the importance of maintaining contact with the MMT, regardless of its frequency, which would imply that students lacking any contact with the MMT during the pandemic were seriously deprived in terms of learning. The literature highlights the importance of guided self-reflective discussions about the process of learning, which should help students assess 
the effectiveness of their learning strategies and discover alternative strategies they could use, including discussions on students' emotions related to learning and how these can facilitate or hinder the learning process (Nugent et al., 2019; Russell et al., 2020). In the field of HME, microanalysis, which involves such discussion, has been proven to help students advance their SRL skills (McPherson et al., 2017; Miksza et al., 2018). In the context of online learning in the time of the pandemic, a need for such discussions is certainly intensified. Hence, taking into account the presented findings, the question arises for HME and MMTs - how to bridge the gap in support to students' development created during the pandemic?

Analysing the messages/short letters students wrote to their teachers, we have generated two key themes - the first one telling what the MMT should $d o$ and does to help student progress, and the second one telling how he/she should be and is. A closer look at some coded segments comprising the codes 'supportive, 'devoted to teaching and students', and 'closer', within the theme 'Teacher needs to be...' indicates the need for emotional support and for the MMT to be a partner in affective interaction (Ivić et al., 2001). The fact that students look upon the MMT as a pillar of strength raises questions of the complexity of the teachers' role in the context of HME, especially in individual teaching. We point out that the code 'Teacher needs to be close(r)', coupled with a need for the MMT to be devoted and supportive, is in congruence with the findings from quantitative analysis. Namely, the coded segments convey the message on the importance of contact with the MMT and that, to feel supported, students need a teacher who is available when they seek help. Students feel supported when they see that the teacher is putting in an effort and when he/she is trying to motivate them. Apart from the need for classes to be more regular, students stress the importance of different teaching methods and feedback for their learning, which is in line with the insights from the literature on how to best support SRL in students. Namely, opportunities for students to practice and develop SRL can be provided by designing learning activities that promote peer learning, critical thinking, use of different learning strategies, etc. (Dignath-Van Ewijk et al., 2013; Nugent et al., 2019; Russell et al., 2020), and by providing good formative feedback (Hattie \& Timperley, 2007; Ion et al., 2017; Nicol \& Macfarlane-Dick, 2006). Appropriate teachers' interventions could potentially raise the self-motivation beliefs in a Forethought phase of the SRL (Zimmerman \& Campillo, 2003).

We could assume that one part of reasons behind the limited contacts is related to technological resources available to teachers and students and their competence to use those resources. With limited organizational and systematic support, they were left to their resources and capacities, which was certainly reflected in the quality of online teaching/learning. Indeed, some teachers responded to the challenge with more success than others, since in 81 coded segments, students expressed their satisfaction with the teaching 
during the pandemic and/or stated that there was no need for improvement, while in 117 coded segments, we could observe that there was room for improvement.

Our findings bring up another important question - how self-regulated are music students? The insights we obtained suggest a strong students' relatedness to the MMT's intervention. This is especially visible from students' letters where they demonstrated strong and diverse demands from the MMT - to give them instructions, to organize for them, to provide, motivate, and put in an effort. The list is long and indicates that students do not have highly developed SRL skills at the end of their three-level specialist music education (Nogaj \& Bogunović, 2015). It also suggests that the studentteacher relationship is more of the 'master-apprentice' kind (Lehmann et al., 2007; Reid, 1997), which brings about difficulties in building students' responsibility for their own professional and personal development, as stated by Gaunt (2007).

\section{Limitations}

This study was exploratory and conducted on a relatively small convenience sample, which limits the generalization of findings. In addition, the research instrument, although it showed good reliability, has been used for the first time. Both limitations call for subsequent research with more participants. Another thing to keep in mind is that students retrospectively assessed the support received before the pandemic, and hence there is a possibility that their answers were "coloured" by their impressions of the present situation. Finally, since "interpretation is inherent to the (TA) analytic process" (Braun \& Clarke, 2020b, p. 13), here we draw attention to the fact that the depth of our findings is conditioned by our skill in applying this method of analysis (Braun \& Clarke, 2020b).

\section{Conclusion}

Considering the importance of fostering SRL skills in the musically gifted students and the importance of SRL skills in the context of online teaching/ learning, we examined whether students in HME perceived the change in the MMT's support to the development of SRL skills during the pandemic. Given that the pandemic is ongoing, we also wanted to obtain insight into students' perspectives on how the MMT can further support their learning.

By analysing the answers of 144 under- and postgraduate music students, we obtained the findings that students perceived their SRL skills as having been supported by the MMT to a greater extent in the period before the pandemic. Further quantitative analysis indicated the importance of maintaining the 
student-teacher connection during the pandemic, since students that had no contact with the MMT perceived lower support to the development of their SRL skills. Our results give ground to conclude that SRL in HME probably relies on the quality of the contact with the MMT. Qualitative analysis of students' expectations from the MMT focused again on the significance of the teacher's role as a partner in affective interaction (Ivić et al., 2001) and informed educational practice by pointing to specific teacher's actions that students perceived as important for their further development.

Based on the results, it may be inferred that HME students count on the MMT's cognitive instructions, motivational interventions, and emotional support, in spite of being involved in the system of music training for over a decade. Evidently, the development of strong SRL and performing skills is not supported systematically and in an adequate manner. These findings call for re-thinking of the SRL model in the specific field such as music education, where we evidence the impact of students' developmental changes, a specific role of motivational and personality features that contribute to the acquisition of SRL skills, as well as educational and personal influences of the MMT and of the HME setting in general. It seems that the SRL model can be affected by the features of the professional setting as well, and that it is worthwhile to investigate further in that direction.

Although the research has its limitations, it is a contribution to a better understanding of the educational needs of the musically gifted in Serbia in the time of the pandemic. Still, it is not limited to this. Regular teacher-student interaction is undoubtedly an essential prerequisite for developing students' SRL skills. However, it is not sufficient in itself. Supporting SRL requires a conscious commitment to it and careful planning of the teaching/learning process. Therefore, further research should explore the MMTs' awareness of the importance of SRL and the ways in which they incorporate support to SRL in their everyday teaching. Furthermore, we point out the importance of exploring the relative significance of teachers' affective role in one-to-one, small and large group teaching setting. Finally, findings that the MMT who supports students' learning is devoted to students and teaching and invests an effort, points to the significance of addressing the topic of teacher's motivation during online education.

\section{References}

Anthonysamy, L., Koo, A. C., \& Hew, S. H. (2020). Self-regulated learning strategies and non-academic outcomes in higher education blended learning environments: A one decade review. Education and Information Technologies, 25, 3677-3704. https://doi.org/10.1007/s10639-020-10134-2

Araújo, M. V. (2015). Measuring self-regulated practice behaviours in highly skilled musicians. Psychology of Music, 44(2), 278-292. https://doi. org/10.1177/0305735614567554 
Barnard-Brak, L., Paton, V. \& Lan, W. (2010). Profiles in self-Regulated learning in the online learning environment. International Review of Research in Open and Distributed Learning, 11(1), 61-80. https://doi.org/10.19173/irrodl.v11i1.769

Bjork, R. A., Dunlosky, J., \& Kornell, N. (2013). Self-regulated learning: Beliefs, techniques and illusions. Annual Review of Psychology, 64, 417-444. https://doi. org/10.1146/annurev-psych-113011-143823

Bogunović, B. (2018). Sight reading strategies and personality dimensions. In R. Parncutt \& S. Sattmann (Eds.), Proceedings of ICMPC15/ESCOM10 (pp. 85-90). Graz, Austria: Centre for Systematic Musicology, University of Graz.

Bogunović, B. i Mirović, T. (2014). Visoko obrazovanje muzički darovitih: studentske procene kompetencija nastavnika [Higher education of musically gifted: Students' estimation of teachers' competencies]. Primenjena psihologija, 7(3), 469-491.

Bogunović, B. \& Vujović, I. (2012). Metacognitive strategies in learning sight-singing. Psihološka istraživanja, 15(2), 115-133.

Bogunović, B., Vujović, I., \& Protulipac, A. (2020). Sight reading in singing and playing. In B. Bogunović \& S. Nikolić (Eds.), Proceedings of the First International Conference Psychology and Music - Interdisciplinary Encounters (pp. 44-52). Belgrade: Faculty of Music.

Boon, E. T. (2020). Self-regulated learning skills of prospective music teachers in Turkey. International Journal of Music Education, 38(3), 415-430. https://doi. org/10.1177/0255761420909919

Braun, V., \& Clarke, V. (2006). Using thematic analysis in psychology. Qualitative Research in Psychology, 3(2), 77-101. https://doi.org/10.1191/1478088706qp063oa

Braun, V., \& Clarke, V. (2020a). Can I use TA? Should I use TA? Should I not use TA? Comparing reflexive thematic analysis and other pattern-based qualitative analytic approach. Counselling and Psychotherapy Research, 0,1-11. https://doi. org/10.1002/capr.1236

Braun, V., \& Clarke, V. (2020b). One size fits all? What counts as quality practice in (reflexive) thematic analysis? Qualitative Research in Psychology, 18(3). 328-352. https://doi.org/10.1080/14780887.2020.1769238

Broadbent, J. (2017). Comparing online and blended learner's self-regulated learning strategies and academic performance. Internet and Higher Education, 33, 24-32. https://doi.org/10.1016/j.iheduc.2017.01.004

Broadbent, J., \& Fuller-Tyszkiewicz, M. (2018). Profiles in self-regulated learning and their correlates for online and blended learning students. Educational Technology Research and Development, 66(6), 1435-1455. https://doi.org/10.1007/ s11423-018-9595-9

Broadbent, J., \& Poon, W. L. (2015). Self-regulated learning strategies \& academic achievement in online higher education learning environments: A systematic review. The Internet and Higher Education, 27, 1-13. http://dx.doi.org/10.1016/j. iheduc.2015.04.007

Christie, H., Barron, P., \& D’Annunzio-Green, N. (2013). Direct entrants in transition: Becoming independent learners. Studies in Higher Education, 38(4), 623637. https://doi.org/10.1080/03075079.2011.588326 
Crawford, J., Butler-Henderson, K., Rudolph, J., Malkawi, B., Glowatz, M., Burton, R., Magni, P. A., \& Lam, S. (2020). COVID-19: 20 countries' higher education intraperiod digital pedagogy responses. Journal of Applied Learning \& Teaching, 3(1), 9-28. https://doi.org/10.37074/jalt.2020.3.1.7

Dabbagh, N., \& Kitsantas, A. (2004). Supporting self-regulation in student-centered web-based learning environments. International Journal on E-Learning, 3(1), 40-47.

Dignath-Van Ewijk, C., Dickhauser, O., \& Buttner, G. (2013). Assessing how teachers enhance self-regulated learning: A multiperspective approach. Journal of Cognitive Education and Psychology, 12(3), 338-358. https://doi.org/10.1891/19458959.12.3.338

Gaunt, H. (2007). One-to-one tuition in a conservatoire: the perceptions of instrumental and vocal teachers. Psychology of Music, 36(2), 215-245. https://doi. org/10.1177/0305735607080827

Gaunt, H. (2010). One-to-one tuition in a conservatoire: the perceptions of instrumental and vocal students. Psychology of Music, 38(2), 178-208. https://doi. org/10.1177/0305735609339467

Habe, K., Biasutti, M. \& Kajtna, T. (2021). Wellbeing and flow in sports and music students during the COVID-19 pandemic. Thinking Skills and Creativity, 39, 2-9.https://doi.org/10.1016/j.tsc.2021.100798

Hatfield, J. L. (2016). Performing at the top of one's musical game. Frontiers in Psychology, 7, 1-16. https://doi.org/10.3389/fpsyg.2016.01356

Hatfield, J. L., Halvari, H., \& Lemyre, P. N. (2016). Instrumental practice in the contemporary music academy: A three-phase cycle of self-Regulated learning in music students. Musicae Scientiae, 21(3), 316-337. https://doi. org/10.1177/1029864916658342

Hattie, J., \& Timperley, H. (2007). The power of feedback. Review of Educational Research, 77(1), 81-112. https://doi.org/10.3102/003465430298487

Heikkilä, A., Lonka, K., Nieminen, J., \& Niemivirta, M. (2012). Relations between teacher students' approaches to learning, cognitive and attributional strategies, well-being, and study success. Higher Education, 64, 455-471. http://dx.doi. org/10.1007/s10734-012-9504-9

Ion, G., Cano-García, E., \& Fernández-Ferrer, M. (2017). Enhancing self-regulated learning through using written feedback in higher education. International Journal of Educational Research, 85, 1-10. https://doi.org/10.1016/j.ijer.2017.06.002

Ivić, I., Pešikan, A., i Antić, S. (2001). Aktivno učenje 2 [Active Learning 2]. Beograd: Institut za psihologiju.

Keyserlingk, L., Yamaguchi-Pedroza, K., Arum, R., \& Eccles, J. S. (2021). Stress of university students before and after campus closure in response to COVID-19. Journal of Community Psychology. https://doi.org/10.1002/jcop.22561

King, F. B., Harner, M., \& Brown, S. W. (2000). Self-regulatory behavior influences in distance learning. International Journal of Instructional Media, 27(2), 147-156.

Klein, P., Ivanjek, L., Dahlkemper, M. N., Jeličić, K., Geyer, M.-A., Küchemann, S., \& Susac, A. (2021). Studying physics during the COVID-19 pandemic: Student 
assessments of learning achievement, perceived effectiveness of online recitations, and online laboratories. Physical Review Physics Education Research, 17(1). https://doi.org/10.1103/physrevphyseducres.17.010117

Lee, J.Q., McInerney, D.M., \& Liem, G.A. (2010). The relationship between future goals and achievement goal orientations: An intrinsic-extrinsic motivation perspective. Contemporary Educational Psychology, 35(4), 264-279. https://doi. org/10.1016/j.cedpsych.2010.04.004

Lehmann, A. C., Sloboda, J. A., \& Woodie, R. H. (2007). Psychology for musicians Understanding and acquiring the skills. NY: Oxford University Press Inc.

McPherson, G. E., Osborne, M. S., Evans, P., \& Miksza, P. (2017). Applying self-regulated learning microanalysis to study musicians' practice. Psychology of Music, 47(1), 18-32. https://doi.org/10.1177/0305735617731614

McPherson, G. E., \& Zimmerman, B. J. (2011). Self-regulation of musical learning: A social cognitive perspective on developing performance skills. In R. Colwell \& P. Webster (Eds.), MENC handbook of research on music learning, volume 2: Applications (pp. 130-175). New York, NY: Oxford University Press.

Miksza, P. (2011). The development of a measure of self-regulated practice behavior for beginning and intermediate instrumental music students. Journal of Research in Music Education, 59(4), 321-338. https://doi.org/10.1177/0022429411414717

Miksza, P. (2015). The effect of self-regulation instruction on the performance achievement, musical self-efficacy, and practicing of advanced wind players. Psychology of Music, 43(2), 219-243. https://doi.org/10.1177/0305735613500832

Miksza, P., Blackwell, J., \& Roseth, N. E. (2018). Self-regulated music practice: Microanalysis as a data collection technique and inspiration for pedagogical intervention. Journal of Research in Music Education, 66(3), 295-319. https://doi. org/10.1177/0022429418788557

Miksza, P., \& Tan, L. (2015). Predicting collegiate wind players, flow, and self-efficacy for self-regulation: An exploratory study of relationships between teachers' instruction and students' practicing. Journal of Research in Music Education, 63(2), 162-179. https://doi.org/1216 10.1177/0022429415583474

Montgomery, A. P., Mousavi, A., Carbonaro, M., Hayward, D. V., \& Dunn, W. (2019). Using learning analytics to explore self-regulated learning in flipped blended learning music teacher education. British Journal of Educational Technology, 50(1), 114-127. https://doi.org/10.1111/bjet.12590

Moore, M. G., \& Kearsley, G. (2005). Distance education: A systems view (2nd ed.). Belmont, CA: Wadsworth.

Moos, D. C., \& Ringdal, A. (2012). Self-regulated learning in the classroom: A literature review on the teacher's role. Education Research International, 2012, 1-15. https://doi.org/10.1155/2012/423284

Nicol, D. J., \& Macfarlane-Dick, D. (2006). Formative assessment and self-regulated learning: A model and seven principles of good feedback practice. Studies in Higher Education, 31(2), 199-218. https://doi.org/10.1080/03075070600572090

Nielsen, S. G. (2015). Learning pre-played solos: Self-regulated learning strategies in jazz/improvised music. Research Studies in Music Education, 37(2), 233-246. https://doi.org/10.1177/1321103x15615661 
Nogaj, A. \& Bogunović, B. (2015). The development of giftedness within the threelevel system of music education in Poland and Serbia: Outcomes of different stages. Journal of the Institute of Educational Research, 47(1), 153-174. https:// doi.org/10.2298/ZIPI1501153N

Nugent, A., Lodge, J. M., Carroll, A., Bagraith, R., MacMahon, S., Matthews, K., \& Sah, P. (2019). Higher education learning framework: An evidence informed model for university learning. Report. Science of Learning Research Centre, The University of Queensland, Australia. https://doi.org/10.14264/348c85f

Panadero, E. (2017). A review of self-regulated learning: Six models and four directions for research. Frontiers in Psychology, 8:422. https://doi.org/10.3389/ fpsyg.2017.00422

Panadero, E., \& Alonso-Tapia, J. (2014). How do students self-regulate? Review of Zimmerman's cyclical model of self-regulated learning. Anales De Psicologia, 30(2), 450-462. https://doi.org/10.6018/analesps.30.2.167221

Puzziferro, M. (2008). Online technologies self-efficacy and self-regulated learning as predictors of final grade and satisfaction in college level online courses. American Journal of Distance Education, 22(2), 72-89. https://doi. org/10.1080/08923640802039024

Reid, A. (1997). The meaning of music and the understanding of teaching and learning in instrumental lesson. In A. Gabrielsson (Ed.), Proceedings of the Third Triennial ESCOM Conference (pp. 200-205). Uppsala, Sweden: European Society for the Cognitive Sciences of Music.

Russell, J. M., Baik, C., Ryan, A. T., \& Molloy, E. (2020). Fostering self-regulated learning in higher education: Making self-regulation visible. Active Learning in Higher Education. https://doi.org/10.1177/1469787420982378

Schunk, D. \& Zimmerman, B. (2007). Influencing children's self-efficacy and self-regulation of reading and writing through modeling. Reading \& Writing Quarterly, 23(1), 7-25. https://doi.org/10.1080/10573560600837578

Serdyukov, P., \& Hill, R. (2013). Flying with clipped wings: are students independent in online college classes? Journal of Research in Innovative Teaching, 6(1), 54-6.

Wang, C. H., Shannon, D., Ross, M. (2013). Students' characteristics, self-regulated learning, technology self-efficacy, and course outcomes in online learning. Distance Education, 34(3), 302-323. https://doi.org/10.1080/01587919.2013.8357797

Yot-Domínguez, C., \& Marcelo, C. (2017). University students' self-regulated learning using digital technologies. International Journal of Educational Technology in Higher Education, 14:38. https://doi.org/10.1186/s41239-017-0076-8

Zimmerman, B. J., \& Campillo, M. (2003). Motivating self-regulated problem solvers. In J. E. Davidson \& R. J. Sternberg (Eds.), The psychology of problem solving (pp. 233-262). New York, NY: Cambridge University Press.

Zimmerman, B. J., \& Moylan, A. R. (2009). Self-regulation: Where metacognition and motivation intersect. In D. J. Hacker, J. Dunlosky \& A. C. Graesser (Eds.), Handbook of metacognition in education (pp. 299-315). New York: Routledge. 


\section{Biti Povezan: Podržavanje samoregulisanog učenja u višem muzičkom obrazovanju pre i nakon pandemije}

\section{Dejana Mutavdžin ${ }^{2}$}

Fakultet muzičke umetnosti, Univerzitet umetnosti u Beogradu

\section{Milan Stančić}

Filozofski fakultet, Univerzitet u Beogradu

\section{Blanka Bogunović}

Fakultet muzičke umetnosti, Univerzitet umetnosti u Beogradu

Tokom onlajn učenja, od studenata se očekuje da preuzmu veću odgovornost za sopstveno obrazovanje, a od nastavnika se očekuje da podrže veštine samoregulisanog učenja svojih studenata. U ovom istraživanju ispitivali smo da li mladi muzičari opažaju razliku u postupcima kojima je nastavnik glavnog predmeta podržavao njihove veštine samoregulisanog učenja pre i tokom pandemije, kao i viđenje studenata na koji način nastavnik glavnog predmeta može dodatno podržati njihovo učenje. Uzorak čine 144 studenta Fakulteta muzičke umetnosti u Beogradu, koji su popunili onlajn inventar sačinjen od 24 pitanja - 17 paralelnih ajtema Likertovog tipa (koji se odnose na postupke kojima je nastavnik glavnog predmeta podržavao veštine samoregulisanog učenja pre i tokom pandemije), a jedno je predstavljalo kratko pismo nastavniku glavnog predmeta. Podaci su analizirani upotrebom $t$-testa za zavisne uzorke i ANOVA-e, kao i upotrebom refleksivne tematske analize. Studenti opažaju da su veštine samoregulisanog učenja u većoj meri ohrabrivane pre nego tokom pandemije. Dodatno, naši nalazi pokazuju da studenti muzike koji sa svojim nastavnikom glavnog predmeta nisu imali neposrednu i onlajn komunikaciju, zasebno, opažaju da su bili manje podržani da samoregulišu sopstveno učenje. Nalazi kvalitativne analize informišu obrazovnu praksu time što ukazuju na konkretne postupke nastavnika koje studenti opažaju kao bitne za njihov dalji razvoj.

Ključne reči: samoregulisano učenje, COVID-19, podrška nastavnika, nastavnik muzike, visoko muzičko obrazovanje

2 dejana.mutavdzin@outlook.com 


\section{Appendix A \\ Results from the Principal Component Analyses of the SRL scale}

Two principal component analyses (PCA), conducted on 17 items referring to the period before and 17 items referring to the period during the pandemic (rotation method: Oblimin, Eigenvalues 0.95), confirmed a three-component solution. The Kaiser-Meyer-Olkin measures verified the sampling adequacy for the analysis, $\mathrm{KMO}_{\text {before }}=.87 ; \mathrm{KMO}_{\text {during }}=.92$, and Bartlett's tests of sphericity indicated that correlations between items were sufficiently large for PCA, $\chi_{\text {before }}^{2}(136)=1273.63, p<.001, \chi_{\text {during }}^{2}(136)=1522.85, p<.001$. Three components referring to the period before the pandemic in combination explained $60.84 \%$ of variance. Three components referring to the period during the pandemic in combination explained $65.85 \%$ of the variance. The obtained solutions, with deviations of individual items, correspond to the structure of the SRL scale's subscales, which can be kept in mind when refining the instrument. Data on the reliability (Cronbach's alpha) of each of the SRL subscales, referring to the period before and during the pandemic separately, are given in Table A1.

Table A1

Reliability of the SRL scale's subscales referring to the period before and during the pandemic $(N=144)$

\begin{tabular}{lccc}
\hline Period & $\begin{array}{c}\text { Forethought subscale } \\
\alpha\end{array}$ & $\begin{array}{c}\text { Performance subscale } \\
\text { Self-reflection subscale }\end{array}$ & $\alpha$ \\
\hline $\begin{array}{l}\text { Before the pandemic } \\
\begin{array}{l}\text { During the } \\
\text { pandemic }\end{array}\end{array}$ & .87 & .75 & .86 \\
\hline
\end{tabular}




\section{Appendix B}

Statistically significant differences between arithmetic means of parallel items of the scale assessing students' perceptions of the MMT's support in fostering SRL skills before and during the pandemic

\begin{tabular}{|c|c|c|c|c|c|c|}
\hline $\begin{array}{l}\text { Item } \\
\text { The MMT encouraged the student ... }\end{array}$ & & $M(S D)$ & $t$-test & $d f$ & $p$ & $r_{p b}$ \\
\hline \multirow{2}{*}{$\begin{array}{l}\text { to build up awareness of the task } \\
\text { importance }(F)\end{array}$} & Before & $4.69(1.87)$ & \multirow{2}{*}{2.26} & \multirow{2}{*}{140} & \multirow{2}{*}{.025} & \multirow{2}{*}{.19} \\
\hline & During & $4.52(1.94)$ & & & & \\
\hline \multirow{2}{*}{$\begin{array}{l}\text { to strive for independent problem- } \\
\text { solving }(\mathrm{P})\end{array}$} & Before & $4.69(1.94)$ & \multirow{2}{*}{3.18} & \multirow{2}{*}{141} & \multirow{2}{*}{.002} & \multirow{2}{*}{.26} \\
\hline & During & $4.39(2.01)$ & & & & \\
\hline \multirow{2}{*}{ to pay attention to difficult parts $(\mathrm{P})$} & Before & $6.13(1.18)$ & \multirow{2}{*}{2.20} & \multirow{2}{*}{140} & \multirow{2}{*}{.030} & \multirow{2}{*}{.18} \\
\hline & During & $5.94(1.46)$ & & & & \\
\hline \multirow{2}{*}{ to use mental rehearsing strategies $(\mathrm{P})$} & Before & $5.02(1.84)$ & \multirow{2}{*}{3.57} & \multirow{2}{*}{141} & \multirow{2}{*}{.000} & \multirow{2}{*}{.29} \\
\hline & During & $4.73(1.99)$ & & & & \\
\hline \multirow{2}{*}{ to challenge oneself $(\mathrm{P})$} & Before & $5.41(1.80)$ & \multirow{2}{*}{3.20} & \multirow{2}{*}{141} & \multirow{2}{*}{.002} & \multirow{2}{*}{.26} \\
\hline & During & $5.14(1.98)$ & & & & \\
\hline \multirow{2}{*}{$\begin{array}{l}\text { to summarize what has been achieved } \\
\text { (S-R) }\end{array}$} & Before & $4.94(1.78)$ & \multirow{2}{*}{2.03} & \multirow{2}{*}{140} & \multirow{2}{*}{.044} & \multirow{2}{*}{.17} \\
\hline & During & $4.77(1.89)$ & & & & \\
\hline
\end{tabular}

Note. $\mathrm{F}=$ Forethought phase; $\mathrm{P}=$ Performance phase; $\mathrm{S}-\mathrm{R}=$ Self-reflection phase. 


\begin{abstract}
Appendix $\mathrm{C}$
Means, standard deviations and two-way ANOVA statistics for the perceived differences in the MMT's support to fostering SRL skills before and during pandemic, for in-person student-teacher contacts; statistically significant, item level
\end{abstract}

\begin{tabular}{|c|c|c|c|c|c|c|c|c|c|c|}
\hline \multirow{2}{*}{$\begin{array}{l}\text { Item } \\
\text { The MMT encouraged the } \\
\text { student ... }\end{array}$} & \multicolumn{2}{|c|}{ G1 } & \multicolumn{2}{|c|}{ G2 } & \multicolumn{2}{|c|}{ G3 } & \multirow[b]{2}{*}{$F$} & \multirow[b]{2}{*}{$d f$} & \multirow[b]{2}{*}{$p$} & \multirow[b]{2}{*}{$\omega$} \\
\hline & $M$ & $S D$ & $M$ & $S D$ & $M$ & $S D$ & & & & \\
\hline $\begin{array}{l}\text { to approach a task with a } \\
\text { plan based on analysing it }(\mathrm{F})\end{array}$ & .64 & 1.41 & -.04 & .50 & .07 & .46 & 8.19 & 2,135 & .000 & 0.31 \\
\hline $\begin{array}{l}\text { to set practicing/learning } \\
\text { long-term goals }(\mathrm{F})\end{array}$ & .48 & 1.37 & .07 & -.44 & -.03 & .63 & 4.11 & 2,135 & .019 & 0.21 \\
\hline $\begin{array}{l}\text { to strive for independent } \\
\text { problem-solving }(\mathrm{P})\end{array}$ & .79 & 1.69 & .14 & .92 & .14 & .69 & 4.19 & 2,135 & .017 & 0.21 \\
\hline $\begin{array}{l}\text { to pay attention to difficult } \\
\text { parts }(\mathrm{P})\end{array}$ & .67 & 1.58 & .05 & .80 & .07 & .65 & 4.48 & 2,134 & .013 & 0.22 \\
\hline to challenge oneself $(\mathrm{P})$ & .76 & 1.48 & .18 & .76 & .03 & .63 & 5.40 & 2,135 & .006 & 0.24 \\
\hline $\begin{array}{l}\text { to make periodic assessments } \\
\text { of progress (S-R) }\end{array}$ & .58 & 1.66 & .05 & .59 & -.10 & .41 & 4.83 & 2,134 & .009 & 0.23 \\
\hline $\begin{array}{l}\text { to devise a plan for } \\
\text { overcoming mistakes (S-R) }\end{array}$ & .64 & 1.54 & .09 & .72 & -.17 & .60 & 5.89 & 2,133 & .004 & 0.26 \\
\hline $\begin{array}{l}\text { to assess own satisfaction } \\
\text { with the achieved (S-R) }\end{array}$ & .61 & 1.50 & -.04 & .56 & -.07 & .53 & 7.01 & 2,134 & .001 & 0.28 \\
\hline
\end{tabular}

Note. $\mathrm{F}=$ Forethought phase; $\mathrm{P}=$ Performance phase; $\mathrm{S}-\mathrm{R}=$ Self-reflection phase; $\mathrm{G} 1=$ Group 1; G2 = Group 2; G3 = Group 3 


\section{Appendix D}

Means, standard deviations and two-way ANOVA statistics for the perceived differences in the MMT's support to fostering SRL skills before and during pandemic, for online student-teacher contacts; statistically significant, item level

\begin{tabular}{|c|c|c|c|c|c|c|c|c|c|c|}
\hline \multirow{2}{*}{$\begin{array}{l}\text { Item } \\
\text { The MMT encouraged the } \\
\text { student ... }\end{array}$} & \multicolumn{2}{|c|}{ G1 } & \multicolumn{2}{|c|}{ G2 } & \multicolumn{2}{|c|}{ G3 } & \multirow[b]{2}{*}{$F$} & \multirow[b]{2}{*}{$d f$} & \multirow[b]{2}{*}{$p$} & \multirow[b]{2}{*}{$\omega$} \\
\hline & $M$ & $S D$ & $M$ & $S D$ & $M$ & $S D$ & & & & \\
\hline $\begin{array}{l}\text { to set specific goals for each } \\
\text { session (F) }\end{array}$ & .50 & 1.58 & -.26 & .98 & .09 & 1.04 & 3.94 & 2,124 & .002 & .21 \\
\hline $\begin{array}{l}\text { to seek advice and help from } \\
\text { different sources }(\mathrm{P})\end{array}$ & .94 & 2.07 & .13 & 1.18 & -.12 & .64 & 4.48 & 2,125 & .013 & .23 \\
\hline $\begin{array}{l}\text { to use mental rehearsing } \\
\text { strategies }(\mathrm{P})\end{array}$ & .94 & 1.70 & .25 & .93 & .12 & .48 & 4.54 & 2,125 & .012 & .23 \\
\hline
\end{tabular}


